\title{
FIRST REPORT OF LIVIDIN AND SPINULOSAIN PEPTIDES FROM THE SKIN SECRETION OF AN INDIAN FROG SHORT COMMUNICATION
}

\author{
Thundiparampil V. Vineeth Kumar, Shyla Gopal and Sanil George* \\ Molecular Ecology Laboratory, Rajiv Gandhi Centre for Biotechnology, \\ Thiruvananthapuram-695014, Kerala, India
}

(Received: June 10, 2015; accepted: July 29, 2015)

\begin{abstract}
Here, we report two novel peptides identified from the skin secretion, having homologies to Lividin and Spinulosain, of an endemic frog, Hydrophylax bahuvistara, of Western Ghats. This is the first report of these peptides from Indian frogs and first identification of Lividin from the Hydrophylax genus. Both peptides exhibited weak antimicrobial activity but very low haemolytic activity. The problems of naming amphibian host defense peptides (HDPs) are also discussed.
\end{abstract}

Keywords: Lividin - Spinulosain - Hylarana - nomenclature - antimicrobial

Development of Host Defense peptide (HDP) libraries from the skin secretion of amphibians is currently gaining momentum not only because of their characteristic feature to disrupt biological membranes [6] but also their proposed therapeutic potentials. HDPs are a cocktail of compounds, especially peptides, having broad spectrum biological activities which act as a first line of defense and secreted upon stress or injury [2]. In this study, two novel peptides having homologies to Lividin and Spinulosain were identified from the skin secretion of Hydrophylax bahuvistara, an endemic frog species of Western Ghats, India. Skin secretion harvesting and primary structure elucidation of the peptides were done as per standard procedures [1]. The peptide sequence obtained was subjected to homology searches using BLAST (NCBI) and their physicochemical properties were computed (http://expasy.org/tools/ protparam.html). Helical wheel of the peptides were plotted (Don Armstrong and Raphael Zidovetzki. Version: Id: wheel. pl, v 1.4 2009-10-20 21:23:36 don ExpIdentified ) followed by chemical synthesis of peptides. Minimal inhibitory concentrations (MICs) were determined [5] against some bacterial strains (Table 1B) and were further confirmed by resazurin microtiter assay (REMA). Hemolytic activities of these peptides on human red blood cells were also assessed [5].

Two different cDNA sequences, have been described one encoding Lividin 8 with 95\% identity to Lividin EV1 reported from Odorrana exiliversabilis (GenBank acc.

*Corresponding author; e-mail address: sgeorge@rgcb.res.in 

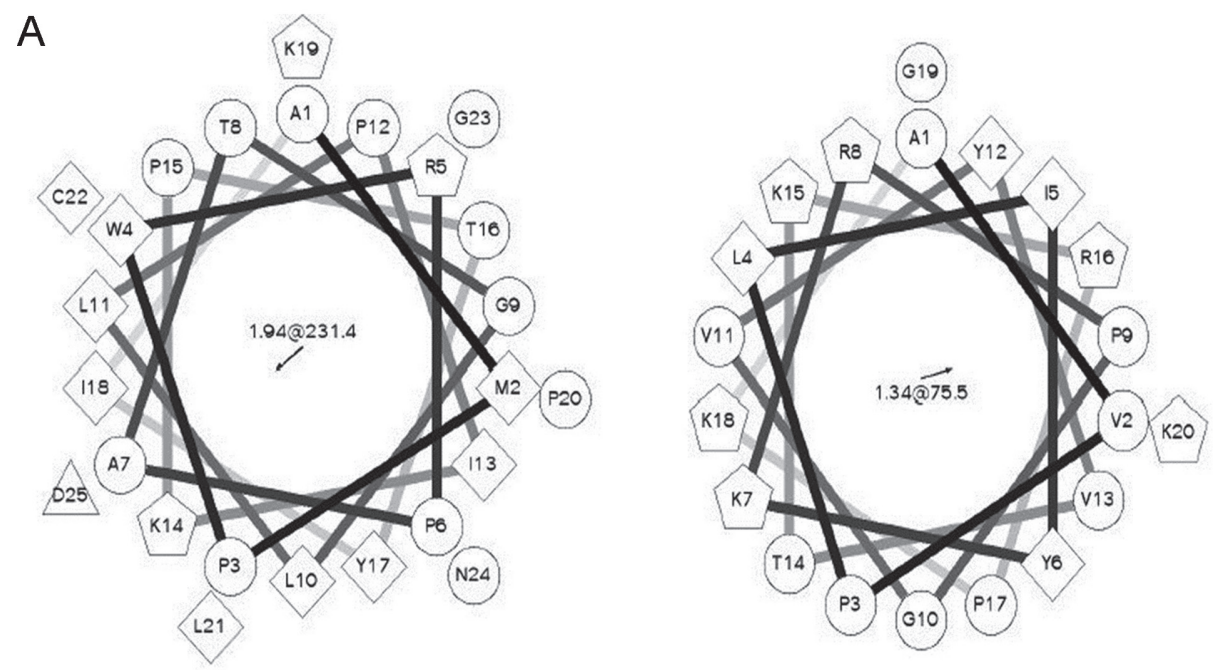

B

\begin{tabular}{|c|c|c|c|}
\hline $\begin{array}{l}\text { NCBI Accession } \\
\text { No }\end{array}$ & $\begin{array}{c}\text { Publication } \\
\text { Year }\end{array}$ & $\begin{array}{c}\text { Current } \\
\text { Name }\end{array}$ & $\begin{array}{c}\text { Corrected } \\
\text { Name }\end{array}$ \\
\hline AIU99956 & 2014 & Lividin-EV1 & AVELIYMREGVIVTKREKGK Lividin 800ev \\
\hline ADM34277 & 2010 & Lividin-MT & AVPLIYNRPGVYVNKREKGK Lividin 8 AMma \\
\hline AGG19129 & 2014 & Odorranain-O-RA & 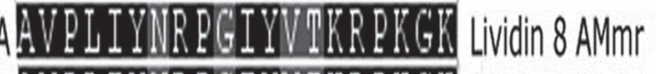 \\
\hline ADPO6110 & 2010 & Odorranain-O-RA & AVRLIYNRPGIYVMKREKGKK Lividin 800an \\
\hline ACA81698 & 2007 & Lividin-8 & AVPLIYMRPGIYVRKREKGR Lividin 8 oDli \\
\hline AEZ52986 & 2012 & Lividin- OT & AVELIYNRESIYVTKREKGK Lividin 800ti \\
\hline ACB05703 & 2009 & $\begin{array}{l}\text { Odorranain-03 } \\
\text { Lividin } 8 \mathrm{HYhn}\end{array}$ & 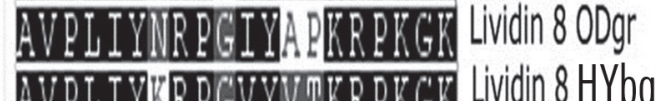 \\
\hline Present Study & & LIVIUIIIO O TIDU & 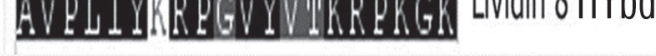 \\
\hline
\end{tabular}

Fig. 1. Helical wheel and multiple sequence alignment of the peptides. A - Helical wheel diagrams of the peptides. The hydrophilic residues are represented as circles, hydrophobic residues as diamonds, negatively charged triangles, and positively charged as pentagons. B - Multiple sequence alignment of Lividin 8 peptides 
no: ADV36193) and a second encoding Spinulosain precursor with $92 \%$ identity to Spinulosain-A1 from Hylarana spinulosa [7]. The new peptides were named according to the recently accepted nomenclature system [4] and submitted to GenBank (GenBank acc. nos: KR995268, KR995269). Both the peptides are cationic with +6 and +2 charges (which is the primary factor responsible for the interaction between biological membrane and peptide [6]), respectively and are hydrophilic (Table 1A). They exhibit weak antimicrobial activity against both Gram-positive and Gramnegative bacteria (Table 1B) and showed no haemolytic activity against human red blood cells even at a higher concentration of $175 \mu \mathrm{M}$. This could be correlated with negative GRAVY index (Table 1A) and helical wheel predictions (Fig. 1A) as there are no perfect demarcation of hydrophobic amino acids to one side of the helix and hydrophilic to the other side, which is against the characteristic feature of antimicrobial peptides. These results go parallel with previous report of Spinulosain from $H$. spinulosa [7], which did not show any antimicrobial activity. There were no previous reports on the activity of Lividin yet. Low antimicrobial activity of some skin derived peptides are hypothesized to be due to the presence of symbiotic bacteria on the skin surface of amphibians that play defensive roles, which can survive only in less toxic environment [2] or they may have antioxidant or synergistic action with other peptides [3]. However, the biological roles of such peptides, enhanced by post-translational modification or synthetic analogues could not be ruled out in a therapeutic context [6].

Table 1

Details of peptides identified from the skin secretion of H. bahuvistara

1A. Physicochemical properties of the peptides

\begin{tabular}{|l|c|c|c|c|c|c|}
\hline & $\begin{array}{c}\text { Number of } \\
\text { amino acids }\end{array}$ & Net charge & GRAVY & $\begin{array}{c}\text { Theoretical } \\
\text { PI }\end{array}$ & $\begin{array}{c}\text { Theoretical } \\
\text { mass }\end{array}$ & $\begin{array}{c}\text { Observes } \\
\text { mass }\end{array}$ \\
\hline Lividin 8 HYba & 20 & +6 & -0.540 & 10.66 & 2270.7 & 2270.7 \\
\hline Spinulosain HYba & 25 & +2 & -0.132 & 9.20 & 2753.3 & 2753.3 \\
\hline
\end{tabular}

1B. Minimal inhibitory concentrations of (MIC) of peptides against microorganisms

\begin{tabular}{|l|c|c|}
\hline \multicolumn{1}{|c|}{ MIC $(\mu \mathrm{M})$} & Lividin 8HLmb & Spinulosain HLmb \\
\hline Gram-positive bacteria & $<200$ & $<200$ \\
\hline Staphylococcus aureus MTCC 9542 & NA & NA \\
\hline Bacillus subtilis MTCC 14416 & $<200$ & NA \\
\hline Bacillus coagulans ATCC 7050 & NA & NA \\
\hline MRSA ATCC 43300 & NA & NA \\
\hline VRE ATCC 29212 & NA & NA \\
\hline Streptococcus mutans MTCC 497 & NA & NA \\
\hline Streptococcus gordonnii MTCC 2695 & NA & NA \\
\hline Gram-negative bacteria & $<200$ & $<200$ \\
\hline Vibrio cholerae MCV09 & \multicolumn{2}{|l}{} \\
\hline E. coli ATCC 25922 &
\end{tabular}

NA: Not appliable. 
The name Lividin was first proposed for peptides isolated from Odorrana livi$d a$ [8]. All the peptides isolated from $O$. livida were given the name Livdin without searching whether they had similarity with other reported peptides. Later, Lividin 1-4 were renamed as Brevinin and Esculentin [4] and proposed that the family name of the peptide should be selected giving priority to publication date. BLAST search gave seven peptides having $80-95 \%$ identity to the Lividin 8 HYba identified in the present study. However they are given different names irrespective of their structural similarity (Fig. 1B) as in the case of Gaegurin and Rugosin, which was renamed later [4]. Lividin $8 \mathrm{HYba}$ identified in the present study showed similarity to Lividins and Odorranains, but on detailed analysis of their sequences and publication dates, it was found that such a sequence first reported was Lividin 8 (GenBank acc. no: ACA81698). Hence we recommend that all the peptides listed in Fig. 1B should be renamed as Lividin 8 . The second peptide was named as Spinulosain without any confusion because on NCBI BLAST, it was found that only one peptide had $>80 \%$ identical sequence (GenBank acc. no: ADV36193). We suggest, that before naming peptides, similar sequences should be searched in existing literatures and databases like NCBI and EMBL and their sequences be carefully analyzed.

\section{ACKNOWLEDGEMENT}

KSCSTE, Govt. of Kerala, is acknowledged for financial assistance.

\section{REFERENCES}

1. Chen, T., Farragher, S., Bjourson., A. J., Orr, D. F., Rao, P., Shaw, C. (2003) Granular gland transcriptomes in stimulated amphibian skin secretions. Biochem. J. 371, 125-130.

2. Harris, R. N., Brucker, R. M., Walke, J. B., Becker, M. H., Schwantes, C. R., Flaherty, D. C., Lam, B. A., Woodhams, D. C., Briggs, C. J., Vredenburg, V. T. (2009) Skin microbes on frogs prevent morbidity and mortality caused by a lethal skin fungus. ISME 3, 818-824.

3. He, W., Feng, F., Huang, Y., Guo, H., Zhang, S., Zheng, Li, Liu, J., Wang, Y., Yu, H. (2012) Host defense peptides in skin secretions of Odorrana tiannanensis: Proof for other survival strategy of the frog than merely anti-microbial. Biochimie 94, 649-655.

4. Thomas, P., Vineeth Kumar, T. V., Reshmy, V., Kumar, K. S., George, S. (2012) A mini review on the antimicrobial peptides isolated from the genus Hylarana (Amphibia: Anura) with a proposed nomenclature for amphibian skin peptides. Mol. Biol. Rep. 29, 6943-6947.

5. Reshmy, V., Preeji, V., Parvin, A., Santhosh Kumar, K., George, S. (2011) Three novel antimicrobial peptides from the skin of the Indian bronzed frog Hylarana temporalis (Anura: Ranidae). J. Pept. Sci. $17,342-347$.

6. Vineeth Kumar, T. V., Holthausen, D., Jacob J., George, S. (2015) Host defense peptides in Asian frogs as potential clinical therapies. Antibiotics 4, 136-159; doi:10.3390/antibiotics4020136.

7. Yang, X., Hu, Y., Xu, S., Hu, Y., Meng, H., Guo, C., Liu, Y., Liu, J., Yu, Z., Wang, H. (2013) Identification of multiple antimicrobial peptides from the skin of fine-spined frog, Hylarana spinulosa (Ranidae). Biochimie 95, 2429-2436.

8. Zhou, M., Chen, T., Walker, B., Shaw, C. (2008) Lividins: Novel antimicrobial peptide homologs from the skin secretion of the Chinese Large Odorous frog, Rana (Odorrana) livida - Identification by "shotgun" cDNA cloning and sequence analysis. Peptides 27, 2118-2123. 